\title{
A Navy of Necessity: Canadian Naval Forces, 1867-2014
}

\section{Roger Sarty}

\begin{abstract}
Le Canada, depuis sa création comme un état-nation en 1867, a été massivement orientée vers le développement de ses terres continentales. Pour cette raison, de nombreux Canadiens ont émis l'avis que la marine a été le produit de pressions de la part d'alliés militaires qui ne tenaient pas compte des besoins nationaux. Cet article soutient l'inverse. Les vraies racines de la marine se trouvent dans les services maritimes gouvernementaux créés au milieu du XIXème siècle pour répondre aux questions urgentes de la souveraineté maritime et de la croissance économique. L'incapacité des alliés à protéger les eaux canadiennes contre les attaques ennemies dans les deux guerres mondiales a mené à une organisation navale élargie. Au début de la guerre froide, les forces navales ont rapidement émergé comme une contribution à l'alliance; contribution qui répondait aux besoins nationaux canadiens et à ses aspirations croissantes d'influence internationale. Ceci s'est encore avéré être le cas dès le début de l'époque suivant la guerre froide.
\end{abstract}

The Royal Canadian Navy was established only in 1910, nearly 43 years after the confederation of Britain's North American colonies in 1867. Even in 1910 Canadians disagreed so intensely about what kind of navy the country needed that the new service was nearly strangled at birth. Panic over the possibility of German seaborne attack at the outbreak of the First World War gave the navy a measure of life-support. Still the government did not provide significant resources until 1917, after a German submarine crossed the Atlantic and destroyed shipping in New England waters, only a few hundred miles south of Nova Scotia. Post-1918 budget cuts forced the service to re-invent itself as a reserve organization, whose mission - despite the ambitions of the small, Britishtrained cadre of professional officers - was coastal defence. Only in the unprecedented disasters of the Second World War did the Canadian service truly become a seagoing force. Drastic post-war cuts were reversed by the onset of the Cold War, which stimulated unprecedented expansion in the 1950s. Heightened Cold War tensions in the 1960s, however, did not ease budget cutbacks resulting from changed government priorities. There were large reductions in the fleet as new programs provided fewer ships to replace ageing hulls. This cycle continues, mitigated periodically when international crises highlight the need for naval forces. No democracy wants to spend more on defence than is obviously necessary. Still Canada's 'sea blindness' is striking in view of its

The Northern Mariner/Le marin du nord XXIV, Nos. 3 \& 4 (Jul. \& Oct. 2014), 32-59

Canadian Military History 23, Nos. 3 \& 4 (Summer \& Autumn 2014), 32-59 
enormous coastline, the economic importance of maritime trade and resources, and the navy's success in promoting the country's international position. ${ }^{1}$

\section{Settling a Continent; Protecting Fisheries, 1763-1902}

The lack of a more robust awareness of the need for maritime forces is the product of history, and the inland location of the country's main centres of population and industry. Much of the impetus for confederation, which originally included only the colonies in the east, came from a drive for continental expansion westward. In 1869 the new 'dominion' took over the vast Hudson's Bay Company lands, the territories from the eastern Arctic to the Rocky Mountains, and in 1871 the Pacific colonies of Vancouver Island and British Columbia joined the federation. The prime inducement for the western colonies to join was the promise of a transcontinental railway. The Canadian Pacific Railway, completed in 1885 , became the federal government's great nation-building project.

Defence was never a priority for Canadians, at least in times of peace, because of the free protection provided by Britain since the time of the American Revolution. The Thirteen Colonies rebelled in 1775 to resist taxes imposed by the British crown to help pay for the British armed forces assigned to protect them. The imperial government never inflicted that burden on the northern colonies, which, aside from Newfoundland and mainland Nova Scotia, had only been seized from France in the Seven Years War (nine actually in North America: 1754-1763). The northern colonies were essentially occupied territories - garrison states - and remained so after the United States secured its independence in 1783. Britain held them during the revolution not only through military strength, but by guaranteeing the language and religious rights of the French, Roman Catholic residents of Quebec. This example of toleration fuelled by political realism, viewed in the American colonies as one of the 'outrageous acts' that justified rebellion, helped prevent French-Canadian cooperation with invading American forces in 1775-76. That invasion was finally defeated in the spring of 1776 when the Royal Navy sailed up the St. Lawrence River to break the American siege of Quebec City. After 1783, the American threat along the new international border, which again flared into invasion in the War of 1812, brought Britain to maintain permanent army garrisons inland and a

1 Recent scholarly accounts that cover the whole history of the navy on the basis of the latest specialist research include Marc Milner, Canada's Navy: The First Century, 2nd ed. (Toronto: University of Toronto Press, 2010); Richard H. Gimblett (ed.), The Naval Service of Canada 1910-2010: The Centennial Story (Toronto: Dundurn, 2010), and its partner volume, Richard H. Gimblett and Michael L. Hadley (eds.), Citizen Sailors: Chronicles of Canada's Naval Reserve, 1910-2010 (Toronto: Dundurn, 2010); and Nicolas Tracy, A TwoEdged Sword: The Navy as an Instrument of Canadian Foreign Policy (Montreal and Kingston: McGill-Queen's University Press, 2012). Michael Whitby, Richard H. Gimblett and Peter Haydon (eds.), The Admirals: Canada's Senior Leadership in the Twentieth Century (Toronto: Dundurn, 2006) provides a comprehensive, analytical account through biographical chapters on the successive directors of the naval service (1910-27) and chiefs of the naval staff (1927-64), and memoirs by commanders, Maritime Command (1964-97). 
strong naval presence on the Atlantic. ${ }^{2}$

By the 1840s-50s, steep costs, persistent colonial demands for more political autonomy, and the fact that the British military presence in North America was a constant irritant in relations with the United States raised grave doubts in Britain about these arrangements. $^{3}$

Indeed, determination that the increasingly self-governing settlement colonies should do more for their own defence was one of the main reasons why the government in London promoted confederation of the British North American colonies. The issue, however, was land forces, not naval forces. Defence of the long land frontier between Canada and the US was one of the largest commitments of the British Army, ruinously expensive, and, as became increasingly evident, futile. Early in the American Civil War, when it looked like Britain might become embroiled in the conflict, the army had rushed 13,000 troops to Canada, bringing the garrison strength to over 18,000, but even this force would have been utterly inadequate in the face of the large scale mobilization of the United States, and that country's skillful use of its new railway network rapidly to deploy those forces over long distances. Diplomacy, always Britain's preferred method for dealing with American sabre rattling, avoided armed conflict. In 1871, just as the Treaty of Washington resolved the most dangerous outstanding issues between Britain and the United States, the last of British Army garrisons in central Canada departed for home.

In the negotiations at the time of confederation, Canada pledged to improve its forces, which meant expanding its land militia organization and beginning to establish such military institutions as a small regular force to train the citizen soldiers. Britain in turn pledged the continued military support to which every part of the empire was entitled. That meant naval protection first and foremost, not as a form of continued charity, but because of mutual interests. Britain's own survival depended upon the security of north Atlantic trade, whose defence incidentally also protected Canada's east coast, the western focal area of the short great circle shipping route to the British Isles. The Royal Navy retained its dockyards at Halifax, Nova Scotia, and at Esquimalt, British Columbia, to support warships of the North America and West Indies station and the

2 The classic and still valuable account is Gerald S. Graham, Empire of the North Atlantic: The Maritime Struggle for North America (Toronto: University of Toronto Press, 1950). Julian Gwyn, Frigates and Foremasts: The North American Squadron in Nova Scotia Waters, 1745-1815 (Vancouver: UBC Press, 2003) fleshes out key parts of the story with much additional work in British and French archives. Graham's final chapter on the late nineteenth and early twentieth centuries features a denunciation of the parochial unwillingness of the Canadian government to support the Royal Navy. On the Pacific see Barry M. Gough, The Royal Navy and the Northwest Coast of North America, 1810-1914 (Vancouver: University of British Columbia Press, 1971).

3 Kenneth Bourne, Britain and the Balance of Power in North America 1815-1908 (London: Longmans, 1967) for the British perspective; C.P. Stacey, Canada and the British Army, 1846-1871: A Study in the Practice of Responsible Government (Toronto: University of Toronto Press, 1936) for the Canadian perspective. For the results of superb research in army and navy archives in Canada and Britain, see J. Mackay Hitsman, Safeguarding Canada, 1763-1871 (Toronto: University of Toronto Press, 1968). 
Pacific station that operated regularly in Canadian waters. Canadian leaders of the late nineteenth century and early twentieth regarded those naval forces and bases as the young country's strategic shield. That shield served mainly as a warning to the United States, the only power in a position to launch an invasion of the northern dominion, and whose offensives in 1775-76 and 1812-14 had been defeated primarily by the dominant strength of the Royal Navy. ${ }^{4}$

There were limits to British naval support. Before confederation the maritime colonies had found it necessary to arm and commission civilian craft as fisheries cruisers to arrest US fishing vessels that violated British North American territorial waters. It was a task the Royal Navy resisted because of the danger that such actions by British warships could precipitate confrontation with the US. The new dominion government armed small patrol vessels in face of a new fisheries dispute in the late-1860s that helped to bring a settlement in the Treaty of Washington in 1871. American abrogation of that settlement in 1886 then resulted in the establishment of a Canadian Fisheries Protection Service on a permanent basis to police the access of US and other foreign fishing vessels and, more generally, enforce regulations designed to conserve fishing stocks. ${ }^{5}$

Intelligence about Russian plans to operate armed merchant cruisers against trade in Canadian waters during the Anglo-Russian war scare of 1877-78 revealed another limit of Imperial naval support. Canada's urgent appeal for protection by trade defence cruisers brought the Admiralty's response that the British fleet would deploy to counter the main concentrations of enemy forces; Canada would have to arm its own trade protection vessels. The Royal Navy provided an old wooden steam corvette, Charybdis, for a scheme to train Canadian fishermen and merchant seamen for military service, but the steep costs for refurbishing the vessel embarrassed the government of Sir John A. Macdonald and killed the project. In 1887, Australia and New Zealand agreed to subsidize augmentation of British cruiser forces in their waters, an apparently more cost-effective method than attempting to raise local forces. Canada immediately rejected the idea, ostensibly on the constitutional grounds that it amounted to taxation without representation (just one of several occasions on which Canadian politicians summoned up this precedent from the American Revolution), but in reality because governments were unwilling to spend heavily on defence when Canada, unlike the Pacific dominions, was close to the north Atlantic centre of British naval power.

4 The principal works on nineteenth century origins of Canadian naval development and the first decades of the navy's history are Gilbert Norman Tucker, The Naval Service of Canada: Its Official History. Vol. I: Origins and Early Years (Ottawa: King's Printer, 1952); Michael L. Hadley and Roger Sarty, Tin-Pots and Pirate Ships: Canadian Naval Forces and German Sea Raiders, 1880-1918 (Kingston and Montreal: McGill-Queen's University Press, 1991), and William Johnston, William G.P. Rawling, Richard H. Gimblett, and John MacFarlane, The Seabound Coast: The Official History of the Royal Canadian Navy, 1867-1939, Vol. 1 (Toronto: Dundurn, 2010).

5 The fullest account of late nineteenth century developments is Thomas Richard Melville, "Canada and Sea Power: Canadian Naval Thought and Policy, 1860-1910" (PhD thesis, Duke University, 1981); on the role of the land forces, and inter-service relations in this and later periods, see Roger Sarty, "Silent Sentry: A Military and Political History of Canadian Coast Defence 1860-1945" (PhD thesis, University of Toronto, 1982). 


\section{The Navy's Troubled Origins, 1902-14}

The impetus for naval action came from revelations of British strategic overstretch, beginning with the war in South Africa in 1899-1902. From the start of that conflict Colonial Secretary Joseph Chamberlain, the tribune of greater imperial unity, called for military contingents from the dominions, and their participation grew in the wake of the initial British defeats. Inspired by the substantial dominions effort, including 7000 troops from Canada, Chamberlain called at the Colonial Conference of 1902 for a permanent combined imperial defence effort. Sir Wilfrid Laurier, prime minister of Canada, rejected the idea. He faced a backlash against the Canadian part in South Africa from French-speaking Quebec that threatened his main political power base. Yet, he was under pressure at least as strong from many English-speaking Canadians to stand by Britain's side. This was the reason why he had been forced against his instincts to approve the despatch of troops to South Africa. Laurier squared this political circle by declaring Canada would develop more capable 'national' armed forces that would assist Britain by relieving her of military commitments in North America. ${ }^{6}$

Naval forces, even if very modest, figured in the national program. British officers serving in Canada had for some time urged that the Fisheries Protection Service should be developed into a naval reserve that in wartime could operate auxiliary patrol vessels - civil craft taken up and armed for naval service. In 1903 the Laurier government ordered two new fisheries cruisers armed with light quick-firing guns that would serve as naval training vessels in the off-season, and prepared legislation to create a 'naval militia' modelled on the country's traditional land force. That legislation never came to Parliament, rather paradoxically, because of the Royal Navy's sudden closure of the Halifax and Esquimalt dockyards late in 1904 and withdrawal of the permanent cruiser squadrons on the North America and Pacific stations. This was part of Admiral Sir John Fisher's scheme to concentrate the fleet in European waters, with squadrons of fast modern ships ready for rapid deployment when and where needed. The Admiralty still wanted the army to maintain its garrison at Halifax to ensure that that strategic port would always be available as a secure base. The army, under intense pressure to economize, appealed to Canada for help, and Laurier uncharacteristically did far more than he was asked. He tripled the size of the small regular land force to more than 3000 troops entirely to relieve the British army's large garrison at Halifax and the smaller one at Esquimalt. This help to the British was popular in English Canada, but equally in French Canada, because it marked the departure of the last 'imperial' troops on Canadian soil. The new garrisons were costly, and Laurier quietly side-lined the naval militia legislation. ${ }^{7}$

6 For the inter-play of British and Canadian policy see Roger Sarty, "Canada and the Great Rapprochement, 1902-1914," in B.J.C. McKercher and Lawrence Aronson (eds.), The North Atlantic Triangle in a Changing World: Anglo-American-Canadian Relations, 1902-1956 (Toronto: University of Toronto Press, 1996), 12-47.

7 The fullest account is Richard Howard Gimblett, "Tin-Pots or Dreadnoughts?: The Evolution of the Naval Policy of the Laurier Administration, 1896-1911” (MA thesis, Trent University, 1981). 
Not untypically of Canada, political scandal provided a further impetus for action. In 1908 Laurier responded to revelations of incompetence and corruption in the Department of Marine and Fisheries by engaging Rear-Admiral Charles E. Kingsmill, a Canadian who had joined the Royal Navy in 1869 when he was 14, to take charge of the government's civil marine fleet. Kingsmill, who came from a politically well-connected family, and had served in Australia where he had experience with the local naval forces there, had a clear idea of what was needed. ${ }^{8}$ From the government's existing marine resources he had to create a force that would meet the country's immediate requirements: defence of the main ports in cooperation with the land forces, and the capacity to patrol the focal areas of shipping off those ports. These of course were the same requirements that had been highlighted in the war scare with Russia in 1877-78.

The effect in Canada of the Dreadnought crisis of early 1909 (the panic in Britain that quickly spread through the empire about the danger of Germany outbuilding the Royal Navy in battleship strength) was to accelerate Kingsmill's program. The Laurier government rejected the Admiralty's advice that the Dominions should build 'fleet units' centred on a dreadnought battlecruiser for deployment in the Pacific to allow the Royal Navy further to concentrate in European waters. The battlecruiser was too expensive, would inflame French-Canadian worries about the country becoming a British proxy in 'imperial' wars, and the Pacific concentration flew in the face of the political reality that the bulk of the Canadian population was in the eastern part of the country. The Admiralty worked with Kingsmill to produce a scheme tailored to Canada's budget and particular requirements: four light cruisers and six destroyers.

Under pressure from English Canadians for dramatic action, Laurier rushed through the creation of the Naval Service of Canada in legislation proclaimed on 4 May 1910. Anticipating charges from Quebec 'nationalistes' that the new service would be nothing more than a branch of the Royal Navy, the government underscored measures that demonstrated its Canadian nature. The new navy, consistent with the approach Laurier had launched in 1902-03, was an outgrowth of the existing Department of Marine and Fisheries. Louis Philippe Brodeur, minister of marine and fisheries, was now doublehatted as the minister of the new Department of the Naval Service. Branches of Marine and Fisheries that might fill a military role in wartime, such as the Fisheries Protection Service and a new chain of coastal radio stations, were transferred to the new department. The legislation, built on precedents of the land forces, asserted the dominion government's full control over the new navy; only the government could assign ships to serve under the Admiralty's orders, and even then the government had to seek the approval of the House of Commons.

This time Laurier's 'national' approach signally failed to bridge the widening gaps in opinion. French Canadian critics, citing the Admiralty's doctrine of central control of naval forces for defence of the Empire, argued that the navy could be nothing more than a branch of the British service. At the same time many English Canadians

8 W.A.B. Douglas, "A Bloody War and a Sickly Season: The Remarkable Career of Admiral Sir Charles Edmund Kingsmill, RN," The Northern Mariner/Le marin du nord XXIV:1 (January 2014), 41-62. 
denounced the nationalist legislation as tantamount to separation from the Empire.

Amid the rising controversy, the navy got off to a promising start. Canada purchased two British cruisers, Niobe (11,000 tons) and Rainbow (3400 tons), which arrived at Halifax and Esquimalt respectively in October and November 1910, and commissioned as His Majesty's Canadian Ships (HMCS). They were crewed on a skeleton basis by 600 active and retired Royal Navy personnel, who had accepted two- to five-year contracts for Canadian service to act as instructors of Canadian recruits. The Royal Naval College of Canada, staffed by seconded British personnel, opened at Halifax dockyard in January 1911, with the first class of 21 Canadian midshipmen. Meanwhile the British shipbuilding and arms manufacturing giant, Vickers Sons and Maxim, established a Canadian subsidiary at Montreal to construct the ten ships of the proposed fleet.

These efforts came to a halt in the general election of September 1911, which brought the Conservatives to power. The Conservative leader, Robert Borden, had won support in Quebec by promising to scrap the Laurier legislation and revive plans for more modest naval development, while appealing to Laurier's pro-Empire critics by suggesting he might offer a financial subsidy to the Admiralty. Once in power, he cut the naval budget to bare subsistence level for the existing skeleton organization. When in 1912 the new first lord of the Admiralty, Winston Churchill, asked for a subsidy, Borden introduced the Naval Aid Bill, which provided \$35 million, enough for the construction of three of the latest dreadnought battleships. The Liberals mounted a filibuster in the House of Commons. The government imposed closure for the first time in Canadian history, but the Liberals then defeated the bill in the unelected upper house, the Senate, where they still had a majority. Asking the Admiralty for advice on a new Canadian naval policy early in 1914, Borden received the unwelcome reply that something like the Laurier fleet would be needed to protect focal areas of shipping off the Canadian coasts against the increasing danger from German surface commerce raiders. By the summer of 1914 the strength of the RCN had been eroded by the departure of British personnel on contract and desertion among the Canadian recruits to about 350 personnel.

\section{The First World War and the Challenge of Trade Defence, 1914-18}

On the outbreak of war there were panics on both coasts because of reports that fast German cruisers that had been in Mexican waters were heading north. On the west coast, Rainbow had been readied for a fisheries patrol with a crew that partly comprised volunteers who had trained with the help of the cruiser's captain, Commander Walter Hose. (This West Coast initiative persuaded the government, early in 1914, to approve the organization of the Royal Naval Canadian Volunteer Reserve, one of the administration's very few acts in support of the navy.) Fortunately Rainbow, in an emergency cruise south to California on 3 August to 2 September made at the urgent request of the Admiralty to protect British shipping, did not encounter the modern German cruiser Leipzig that had come north from Mexican waters. The enemy vessel would have completely outclassed the older, slower, Canadian ship with her partly trained crew. On 25 August the large Japanese cruiser Izumo and, on 30 August the modern 
British cruiser Newcastle, arrived at Esquimalt to protect shipping in the northeast Pacific.

On the east coast, two British cruisers headed north from Bermuda to patrol the vital trade routes off New York and Nova Scotia during the last days of peace, and were reinforced soon after the outbreak of war by additional cruisers from the UK. Halifax immediately became the base for British trade defence operations in northern waters. Niobe joined the British force in September, her crew built up by volunteers, members of the Newfoundland division of the Royal Naval Reserve, and borrowed British personnel. The Canadian ship participated in patrols off New York and Virginia to guard against escape by the many fast German liners and merchantmen that had interned themselves in ports of the neutral United States.

Borden, eager to bury the contentious Canadian navy issue, willingly accepted British advice that Canada could best contribute to the imperial war effort by providing land forces. Thus began the despatch of nearly half a million troops during the war to field the large Canadian Corps on the Western Front.

The beginning of German submarine warfare against allied merchant shipping in the spring of 1915 raised profound doubts about the ability of the RN to protect the Canadian east coast. In particular, the destruction of the liner Lusitania, close by the major British base at Queenstown in Ireland, raised near panic in Ottawa about the safety of the many troopships that sailed from Canada's ports through very thinly protected waters. In response to a false alert that U-boats had crossed to the north-western Atlantic, the commander of the British trade defence forces, Vice-Admiral Sir George E. Patey, confessed his ships were sitting ducks, and sought protection in Halifax harbour behind a newly installed anti-submarine net, and the small, lightly-armed steamers of the Fisheries Protection Service that since mobilization had carried out harbour entrance patrols under naval direction (one of the products of the excellent mobilization planning Kingsmill and his small staff had carried out in cooperation with the militia department and other government authorities in 1911-14). Thus began the Canadian build-up of a flotilla of dozen anti-submarine craft that initially comprised Fisheries Protection Service and other civil government ships commissioned into the navy, and large yachts and coastal steamers that were purchased or chartered and equipped with a few light guns. The navy brought Niobe, which was now in need of a major refit, alongside at Halifax dockyard, and converted her into a barracks and headquarters for the coastal patrol; her crew were reassigned to the anti-submarine vessels. Here was a dramatic example of how submarine warfare had transformed trade protection.

In November 1916 U-53 appeared off Nantucket Island on the Massachusetts coast, and sank five allied steamers, while destroyers of the neutral US Navy rescued the crews. This confirmation of the transatlantic capability of the submarines brought an emergency building program of 130 -foot anti-submarine trawlers and 60-foot drifters in Canadian shipyards. In the spring and summer of 1918 these craft were rushed to completion to expand the Canadian force to some 130 vessels, crewed by about 5000 personnel - mostly very young volunteers, stiffened by personnel from the Newfoundland RNR - whose main role was to screen transatlantic merchant ship 
convoys as they formed up off Halifax and Sydney, Nova Scotia. The Canadian vessels also escorted smaller coastal convoys between Canadian, Newfoundland and US ports. The convoy system proved a brilliant success in protecting merchant shipping. When in August-September 1918 three large German submarines operated on the Canadian east coast, they were unable to locate any major ships, save two that had sailed unescorted. Thus the U-boat commanders instead attacked the fishing fleets off Nova Scotia and south of Newfoundland, inflicting heavy losses - although there were only a few casualties among the fishermen. The submarines respected 'cruiser warfare' rules with the unarmed schooners and trawlers, giving the crews time to get clear in boats. The arrival of the hundreds of survivors on shore, however, created alarm among the population, and produced scathing criticism of the navy.

\section{Austerity Again, and Tensions on the Pacific, 1919-39}

The prime minister now admitted the need for a national navy organized much as in Laurier's legislation, which Borden's government had never in fact repealed or amended. In August 1918 the Admiralty proposed closer integration of the dominion services under London's control at the very moment $U-156$ was destroying the fishing fleet off Borden's home province of Nova Scotia. Borden led the dominion premiers in rejecting the Admiralty's bid, and reviving an initiative that had been overtaken by the outbreak of the war for a senior British officer to tour the Empire to gather information and offer advice for the development of the dominions' services. This was the origin of Admiral Lord Jellicoe's mission in 1919. Jellicoe's Canadian report was closely based on detailed studies of wartime experiences by the Canadian naval staff. What appeared to be the most realistic of the most modest options looked much like the Laurier navy, with three light cruisers for trade defence in addition to a force of submarines, destroyers, and patrol vessels that the war had shown to be necessary for coastal defence. So vehement was opposition in Cabinet and the government caucus to substantial expenditure that, in 1920, the navy got a much scaled-down version: a single light cruiser, two destroyers and two submarines, all vessels the Admiralty provided free of charge from wartime construction that was now surplus. ${ }^{9}$

Jellicoe confirmed the Canadian naval and general staff's appreciation that the most likely future enemy was Japan. The Canadian government's greatest worry was less Japan's expansion of its sphere of influence in China and Siberia than the toxic effect of this expansion on relations between Canada's most important international partners, Britain and the United States. The Americans, who had long opposed Japanese claims on China, were profoundly suspicious of the Empire's alliance with Japan. At the Imperial Conference of 1921 Arthur Meighen, Borden's successor as prime minister and leader of the Conservative Party, weighed in with British ministers and officials who favoured abrogation of the alliance, which was due for renewal. Meighen warmly supported acceptance of US President Warren Harding's invitation of the Pacific powers to attend a conference in Washington in December 1921 to February 1922 to resolve outstanding

9 James Eayrs, In Defence of Canada: From the Great War to the Great Depression (Toronto: University of Toronto Press, 1964), chapter IV. 
issues and address the nascent naval building race resulting from large-scale American and Japanese wartime naval expansion. The retired Borden attended the conference as the senior Canadian representative on the British Empire delegation. He did everything possible to promote the successful outcome: multilateral treaties for peaceful resolution of disputes (which from the British and Canadian perspective took the place of the alliance with Japan), and the important agreements on naval arms limitations. In the naval agreements, Britain accepted parity with the United States Navy, a tectonic shift in the international balance of power, but one that did not initially trouble the Canadians who had for some time regarded the American fleet as a supplement to the Royal Navy's strategic shield.

The Liberals, under William Lyon Mackenzie King, came to power in the general election of December 1921, in the midst of the conference. King's campaign had focused on the excessive war effort of the Borden administration that had left the country with 60,000 war dead and a large national debt. King pledged to slash defence spending. The navy had to surrender the cruiser and two submarines received from the $\mathrm{RN}$, leaving just two 1000-ton destroyers, one for each coast. The regular force included only 500 personnel, among whom only about 60 were executive branch officers. Most of the latter were graduates of the now shuttered Royal Naval College of Canada who had served in the British fleet during the war to gain professional experience. Kingsmill's successor as director of the naval service, Commodore Walter Hose, had commanded the antisubmarine flotilla on the east coast in 1917-18, and his program was shaped by the lessons learned in that example of desperate eleventh hour improvisation. $\mathrm{He}$ reorganized the service as a reserve organization, so that crews could more effectively be mustered in a future emergency. The Royal Canadian Naval Reserve included professional seamen who received periodic naval training at Halifax and Esquimalt, and the Royal Canadian Naval Volunteer Reserve, established in units at cities across the country, gave training in the evenings to citizen sailors who need not have any marine experience.

Another lesson from the war was the need to develop Naval Service Headquarters (NSHQ) in Ottawa as a naval intelligence centre. In 1914-16 the British cruiser force commanders had essentially taken over the establishments at Halifax and Esquimalt, communicating with the Admiralty and British intelligence offices in Newfoundland and Bermuda, but often not even copying NSHQ. With the introduction of the convoy system in 1917, in which Canadian ports played a vital role, the British dispatched Rear-Admiral B.M. Chambers to run the organization on the east coast, which he did capably, with largely Canadian staff, but his chain of command was to the Admiralty. Kingsmill appointed Hose to run the expanded anti-submarine flotilla - as a Canadian organization under Canadian control - in order to gain some grip on what was happening on the country's own shores. (Interestingly, Hose, a passionate Canadian nationalist, was British and had transferred to the RCN from the RN only in 1912.) Negotiations in 1919-20 reached an amicable solution. The Admiralty designated NSHQ as its intelligence centre in North America, recognizing that it had better communications with the coasts of both Canada and the United States than did either Bermuda or Newfoundland. The organization was run, however, by a qualified RN officer, usually a 
senior commander in rank, who was seconded to the RCN as its director of naval intelligence.

Hose succeeded Kingsmill in 1921; a tenacious and effective administrator, he got on well with the prime minister, Mackenzie King, whom he educated in naval affairs. What the service needed, he argued, was a minimum of six destroyers, to serve as a striking force to back up auxiliary coastal patrol vessels. Destroyers, which neither the RN nor USN, after the United States' entry into the war in April 1917, could supply to Canada during the U-boat attacks in 1918, were what the east coast patrol had needed to deal effectively with powerful sea raiders. The destroyer force was now required on the west coast in view of Canada's utter dependence upon the protection of the US Navy, since the Washington Treaties had confirmed the US as the dominant western power in the Pacific. In the event of a Pacific war, US forces might well occupy the British Columbia coast unless Canada had the armed strength to assure that Japan could not route raiding forces through Canadian waters, which were on the short great circle route between North America and the western Pacific. The King administration approved the acquisition of two modern fleet destroyers, larger and more capable than the vessels of the type from the First World War then in the fleet. The new ships were built in Britain and commissioned as HMC Ships Saguenay and Skeena (1337 tons) in 1931, after the King government had been defeated in the election of 1930, and the onset of the Great Depression brought deep cuts in the armed forces.

Hose retired in 1933, having groomed as his successor Commodore (later Admiral) Percy W. Nelles, who had impressed senior Royal Navy officers when seconded for service in British warships. Nelles was one of the very first Canadian officer cadets; he had started naval training in Fisheries Protection Service ships in 1909, the year before the navy was established. His appointment was 'chief of the naval staff', Hose having changed the old designation 'director of the naval service' to indicate that the navy, although much smaller than the militia (as the Canadian Army was known until 1940), was equal in status.

King and the Liberals returned to office in the fall of 1935, against the backdrop of the crisis resulting from the Italian invasion of Ethiopia. As the prime minister reluctantly conceded the need for some measure of rearmament, the navy had ceased to be politically controversial. To the contrary, the service was now positively useful to King in balancing the views of his large Quebec constituency with those of English Canadian supporters. This was in part the politics of conscription. The Borden government had alienated French Canada in 1917 by introducing compulsory military service to reinforce the Canadian Corps on the Western Front. The political foundation stones of King's rearmament effort were pledges that there would be no conscription in a future war, and that nothing in the program was designed for the despatch of an overseas expeditionary force. The virtue of naval forces was their modest demand for manpower, and the fact that Canada's strategic maritime geography meant that a large part of the navy would in any conceivable eventuality be based at home.

One of the top priorities in the rearmament program was completion of the basic flotilla for six modern destroyers, the minimum standard for one coast. In 1937-38 the 
Royal Navy supplied at discount prices four ' $\mathrm{C}$ '-class destroyers that were near sisters of Saguenay and Skeena. With the growing danger of a two-ocean war against both Japan and Germany, the naval staff had increased the minimum requirement to 18 destroyers, including some of the big new Tribal-class destroyers (1900 tons). There were no additional British warships available, and the naval staff repeated with increasing urgency calls to start a building program in Canada of destroyers or equivalents, and also minesweepers and coastal patrol vessels. The government was unwilling because of the high costs of developing naval shipbuilding capacity, and the fact that the technical expertise required could only be mustered in a cooperative program with the Royal Navy, the kind of prominent commitment to joint action with the imperial government the government wished to avoid.

The prime minister himself, however, sanctioned secret planning with the Royal Navy staff at Bermuda for trade defence, including preparations for convoy, in 1938-39. When on 25 August the Admiralty asked for permission for the cruisers based at Bermuda to take up station at Halifax, the government immediately warmly welcomed the ships. Shortly thereafter, the government quickly gave approval for NSHQ to bring the North American shipping intelligence organization into operation by calling out retired Canadian and British naval officers resident in North America to US as well as Canadian ports. In fact, nothing showed more clearly the pro forma nature of the government's separate declaration of war on Germany on 10 September than the manner in which all three Canadian services carried out mobilization of coastal and trade defence measures from late-August in lock step with the British services. The government was acutely aware of the shortcomings of its own rearmament program, and the resulting dependence of the security of the east coast on the Royal Navy. ${ }^{10}$

\section{The Second World War: A Blue Water Navy, 1939-45}

With the outbreak of war, the government's reservations about shipbuilding disappeared. King hoped to limit Canada's participation to naval and air forces, and agreed to send a single infantry division to Britain only under pressure from his EnglishCanadian ministers who remembered the legacy of the Canadian Corps of the First World War. King was determined that the division, or at most two, should be the full extent of the expeditionary force, and thus agreed to pour resources that were vast in Canadian terms into the British Commonwealth Air Training plan, and, as is less well-known, into naval expansion. Over-ruling querulous finance officials who urged that the Depression-

10 The original official histories of the navy in the Second World War are Gilbert Norman Tucker, The Naval Service of Canada: Its Official History. Vol. II: Activities on Shore (Ottawa: King's Printer, 1952) and Joseph Schull, The Far Distant Ships: An Official Account of Canadian Naval Operations in the Second World War (Ottawa: King's Printer, 1950). These have now been updated by W.A.B. Douglas, Roger Sarty, and Michael Whitby, with Robert H. Caldwell, William Johnston, William G.P. Rawling, No Higher Purpose: The Official Operational History of the Royal Canadian Navy in the Second World War, 19391943, Vol. II, Part I (St. Catharines, ON: Vanwell Publishing, 2002) and A Blue Water Navy: The Official Operational History of the Royal Canadian Navy in the Second World War, 1943-1945, Vol. II, Part 2 (St. Catharines, ON: Vanwell Publishing, 2002). 
wracked economy could fund the building of only a few hulls per year, King directed that the country's small shipbuilding industry should immediately produce at full capacity 92 coastal defence vessels of the latest British types. Of these, 64 were the whaling-type patrol vessel later named the 'corvette', a commercial design selected by the Admiralty because it could be readily produced by non-naval yards, and 28 Bangor-class fleet minesweepers. ${ }^{11}$

The government also approved orders for the construction in British yards of four Tribal-class fleet destroyers. The navy's hope was that these big ships could be deployed in combat theatres overseas, to win recognition for the service abroad, and within Canada to build support for an ocean-going fleet in the post-war era. Meanwhile, the navy endeavoured to strengthen its status by asserting more effective control in home waters. The senior naval officer at Halifax became commanding officer Atlantic Coast, whose authority extended over the whole of the country's Atlantic frontier, from the Arctic to US waters. In contrast to the First World War, Canadian staffs organized and dispatched convoys. When, in October 1939 the $3^{\text {rd }}$ Battle Squadron of the British fleet took up station at Halifax to provide anti-surface-raider protection to the convoys, the Canadian staff arranged for the British rear-admiral commanding to fly his flag on a yacht moored alongside the dockyard, a signal that he did not control port services and intelligence as British cruiser commanders had effectively done in 1914-18.

The successful German offensives against Norway, France and the Low Countries in the spring of 1940 multiplied opportunities as well as pitfalls in the navy's quest for recognition at home and abroad. Plans for the orderly development of the fleet, first for coastal and trade defence in North American waters with the new 'auxiliary' fleet of corvettes and Bangors, and then overseas deployments with larger warships went out the window. Britain urgently needed destroyers, and Canada sent all four that were ready for extended operations. Maintenance of that commitment by the dispatch of refitted ships to replace those due for refit in fact absorbed all seven Canadian destroyers, which battle losses soon reduced to six ships, and then in December 1940 to five. After initial operations on the French coast in May and June, the Canadian ships were engaged in the intense struggle to protect convoys in the western approaches to the United Kingdom. Access to bases on the French coast allowed the U-boat force to strike in greater strength and further and further out to sea as the British desperately endeavoured to extend the range of the thinly-stretched anti-submarine escort force. ${ }^{12}$

During the winter of 1940-41 the RCN rushed to the Western Approaches the first ten corvettes to complete in Canadian yards, together with the four most capable of six old former US destroyers that the RCN crewed to help the RN overcome its shortage of crews. This effort helped the RN extend anti-submarine escort to the west of Iceland,

11 James Pritchard, A Bridge of Ships: Canadian Shipbuilding during the Second World War (Montreal and Kingston: McGill-Queen's University Press, 2011).

12 The pioneering scholarly studies of the RCN in the Battle of the Atlantic are Marc Milner's North Atlantic Run: The Royal Canadian Navy and the Battle for the Convoys (Toronto: University of Toronto Press, 1985) and The U-Boat Hunters: The Royal Canadian Navy and the Offensive against Germany's Submarines (Toronto: University of Toronto Press, 1994). 
but to no avail. Using modern radio communications and 'pack' tactics, the German submarines were able to find and strike at convoys on the high seas between Newfoundland and Iceland, when no anti-submarine escorts were present. The Admiralty asked the RCN to redeploy its forces to help create the Newfoundland Escort Force to cover the mid-ocean gap. This Canada willingly did in June 1941, and then began to pour in new corvettes as they completed. RCN ships accounted for about half of the fifty escorts in the new force, and the Canadian staff asked for recognition of this significant effort by making the new force a Canadian command. The Admiralty agreed because they well knew Commodore L.W. Murray, the nominated officer, and had confidence in him. Murray, a member of the first class of midshipmen in the Canadian naval college, had, like all the small cadre of regular officers, spent a third or more of his career training and serving in RN establishments and ships under arrangements made to overcome the limited facilities in the truncated Canadian service. He worked under the direction of the British commander-in-chief Western Approaches in Liverpool. Still, it was a prominent command appointment in the central part of the major theatre of the maritime war, an enormous achievement for a service that had barely existed in 1939, and the result of the unexpected challenges of submarine warfare. Similarly, the young Canadian regular force officers who commanded the destroyers that led the escort groups had very great responsibilities - control over six or eight escorting warships and the safekeeping of sixty or more merchant vessels.

The corvettes were not designed for transatlantic operations, but they were longranged and seaworthy, even if the wild movement of their rounded hulls made the lives of their crews - almost all volunteer reservists who in many cases had only been a few months in the navy - living hell. Most important, they were the only ships available for convoy escort; without them the convoy system - the only effective means to counter the U-boat assault and keep supplies moving to the British Isles - could have collapsed.

Many of the corvettes were in a desperate state. They had been rushed into service without proper fitting out completion and missing important pieces of equipment that were in short supply. Among the crews often only the captain (invariably a merchant mariner from the naval reserve) was a competent navigator. ${ }^{13}$ The Canadians were supposed to be relieved in September 1941, when the Americans took over the defence of Iceland and the US Navy began to escort convoys from Halifax to that island. The change was supposed to allow the RCN ships to move from St. John's to British bases to reinforce the $\mathrm{RN}$ in the western approaches, and have a chance to complete their equipment and the training of the crews. Admiral E.J. King, commander of the US Atlantic Fleet, however, refused to commit all his destroyers - the only anti-submarine vessels he had - to convoy operations, and asked the Canadians to stay in Newfoundland, where all escort forces came under US Navy command, to cover the slow and, as it proved, most vulnerable convoys. Thus the Canadians continued to assign newly-

13 Ken Macpherson and Marc Milner, Corvettes of the Royal Canadian Navy 1939-1945 (St. Catharines, ON: Vanwell Publishing, 1993); David Zimmerman, The Great Naval Battle of Ottawa (Toronto: University of Toronto Press, 1989). Alan Easton, 50 North: An Atlantic Battleground (Toronto: Ryerson Press, 1963), the memoir of a Naval Reserve corvette commander, is among the finest Battle of the Atlantic memoirs from any nation. 
completed corvettes, with only partly-trained crews, to Newfoundland to strengthen the convoy screens.

A second relief plan, scheduled for the winter of 1941-42, fell apart as a result of the United States' entry into the war with the Japanese attack on Pearl Harbor on 7 December 1941. US destroyers had to be removed from Newfoundland for service in other theatres just when, in January, U-boats stormed in to attack shipping on the coasts of Newfoundland, Nova Scotia, and on the US eastern seaboard. The prompt organization of emergency coastal convoys on the Canadian coast persuaded the U-boats to seek easier targets in American waters, where the US Navy did not introduce a comprehensive convoy system until August. The Canadians and British endeavoured to secure the transatlantic route by running convoys to Boston and then New York, and the Canadians even ran special tanker convoys to and from the Caribbean, the main source of oil for eastern Canadian refineries that nearly went dry because of heavy losses on the US coast. At the same time the Canadians had fully to maintain their commitment to the transatlantic escort force to help compensate for the departure of the American destroyers. A notable feature of the Canadian effort was that the navy kept minimum forces in home waters, even when U-boats penetrated the Gulf of St. Lawrence and sank a dozen merchant vessels and warships in August-September 1942 because of the allied priority for the defence of transatlantic shipping. ${ }^{14}$

No early reinforcements were available because, on British advice, since late 1940, expansion of Canadian shipbuilding focused on the production of merchant ships, so work to build improved corvettes and the new more capable ocean escort, the frigate, did not begin until 1942. When the US Navy, with British and Canadian support, finally completed convoy arrangements on the American coast and in the Caribbean during the fall of 1942, the U-boat fleet, now much expanded to a force of some 200 operational submarines, concentrated for the heaviest attacks of the war on the mid-ocean convoys. The escorts were thinly stretched, and the Canadians, who carried some fifty percent of the burden, particularly so, in ships that had still not been updated with the latest antisubmarine detectors and armament. After two convoys under Canadian escort suffered heavy losses, early in 1943 the British re-assigned the Canadian groups to the eastern Atlantic and Mediterranean, so they could re-equip and train at British bases, while operating in less ferocious weather conditions. The British groups that replaced the Canadians on the North Atlantic also suffered heavy losses, while the Canadians, with some new equipment, performed very well in the eastern Atlantic. The British thus moved the Canadians back to the North Atlantic as part of a concentration of force that in May 1943 drove back the U-boats from the main convoy routes.

At this moment of crisis the RCN achieved recognition of its leading part in the war against the U-boats. Urgently seeking more effective control over transatlantic operations, the Anglo-American combined chiefs of staff who coordinated western allied strategy endeavoured to join the multiplicity of British, Canadian and American commands in the Atlantic into one or two super commands under senior British and

14 Roger Sarty, War in the St. Lawrence: The Forgotten U-Boat Battles on Canada's Shores (Toronto: Allen Lane, 2012). 
American admirals. The effect would be to cut Canada out of direction of the campaign. Admiral Nelles interceded with Admiral King, who now had the dual appointments of commander-in-chief US Fleet and chief of naval operations. Nelles persuaded the American chief that the logical solution was to eliminate the mid-Atlantic division between British control in the east and American control in the west, and rather have the Americans take end-to-end control of convoys routed south of New York, and leave operation of the northern convoys to Canada and Britain. Already, since January 1942, the RCN had been filling in for the US escort force that had had to withdraw from Newfoundland, and it was an anomaly that Admiral Murray was still under US command. Nelles's proposal became the basis for the new organization agreed at the AngloCanadian-American Atlantic Convoy Conference that Admiral King hosted in Washington in March 1943. A new allied theatre, the Canadian Northwest Atlantic with headquarters at Halifax, was to control all allied convoys on the routes north of New York. Admiral Murray received the new appointment effective 30 April 1943, which included command of the Canadian Atlantic Coast as well as Newfoundland, making him the only Canadian of any service to command an allied theatre. Canada had become a full, if junior, partner in the Atlantic war.

Still, because of pressure on all allied resources, there was slow progress in modernizing the corvettes that continued to make up the bulk of the Canadian Atlantic fleet. The naval minister, Angus L. Macdonald, warned of rising discontent among the volunteer reservists - the citizen sailors - who formed the bulk of the escort crews, feared a scandal. He replaced Nelles as chief of the naval staff at the beginning of 1944, paradoxically just as the corvette modernization program began to produce results, improved escort types were completing at Canadian shipyards, and other capable escorts were being supplied by the British whose manpower shortage was becoming increasingly grave. ${ }^{15}$

The navy continued to expand, and the fleet grew more dramatically still as large numbers of new ships commissioned. From a grand total of only 6 sea-going warships and 3500 personnel, regular force and reserve, in September 1939 the service had grown to 100 seagoing warships and 48,693 personnel in January 1943; by January 1945 there were 250 sea-going warships and 87,141 personnel. In the Atlantic, the fleet played a prominent part in the liberation of Northwest Europe. From January 1944 the RCN took over all convoy escort across the North Atlantic to allow the Royal Navy to build up its forces for the invasion at Normandy on 6 June 1944. At the same time, a hundred RCN warships crewed by 10,000 RCN personnel, participated in all phases of the invasion: Canadian minesweepers helped clear the heavily-mined waters off the beaches on the night of 5-6 June ahead of the main invasion fleets; Canadian troopships and landing craft put British and Canadian troops ashore; Canadian fleet destroyers - including the Tribals built in British yards - delivered gunfire against German defences; and Canadian antisubmarine warships escorted the invasion forces and scoured the English Channel for German submarines. The Canadian navy remained fully engaged in these tasks,

15 Richard O. Mayne, Betrayed: Scandal, Politics and Canadian Naval Leadership (Vancouver: UBC Press, 2006). 
supporting the delivery of supplies to the allied armies liberating Europe, and clearing the European coast of German forces, until the German surrender in May 1945. The powerful German submarine force continued to pose a lethal threat by introducing the snorkel that allowed the U-boats to run submerged for weeks at a time and avoid detection by allied airborne and naval radar. The navy suffered its heaviest losses of the war in the offensives of 1944-45, losses that continued to the bitter end. On 16 April 1945, the snorkel-equipped $U-190$ torpedoed the minesweeper HMCS Esquimalt within sight of the Halifax headlands, and she went down with heavy loss of life.

The outbreak of war on the Pacific in December 1941 did not distract the RCN from its Atlantic focus. Long-standing worries about uninvited American military intervention in British Columbia had been set to rest in joint defence planning with the US forces. These efforts stepped into high gear in August 1940, when Mackenzie King and Roosevelt, in the wake of the German conquest of Europe, established the Permanent Joint Board on Defence, with senior representatives from the armed forces and foreign services of the two nations, to oversee cooperative continental defence measures. Under these agreements, Canada assigned three armed merchant cruisers (the Prince-type coastal British Columbia liners that had been taken up for naval service) and a small number of the new corvettes and Bangors to patrol the coast and the main harbour approaches. The country obtained considerable leverage with this small force in June 1942, when the Japanese attacked Dutch Harbor in Alaska, and occupied two of the Aleutian Islands as part of an offensive whose main focus was the island of Midway. Although the US Navy achieved a stunning victory over the main Japanese fleet at Midway, the Americans were hard-pressed to reinforce Alaska, and particularly needed escort ships for troop and supply convoys. The RCN quickly agreed to help, assigning the armed merchant cruisers and two corvettes for duty in Alaskan waters. Because the US Navy had not been able to build up escort forces prior to Pearl Harbor as a result of the finely balanced political struggles over intervention in the war, wartime military assistance on the West Coast was thus, against all odds, from Canada to the United States.

Anglo-American grand strategy was guided by the 'Germany first' principle, but Canada, like Britain, was committed to transfer forces to the Far East for offensives against Japan following the defeat of Germany. In contrast to the predominance of smallship anti-submarine and littoral operations in the Atlantic, the war with Japan featured full fleet operations, and on that fact the Canadian naval staff pinned its hopes for the future. Plans that took shape in 1943 were to build up a national task force of five cruisers, two light fleet aircraft carriers, three flotillas of modern fleet destroyers (as compared to the equivalent of a single flotilla (six ships) of this type in the Atlantic fleet), together with large numbers of the most modern anti-submarine ships from the Atlantic upgraded with improved anti-aircraft armament. The plan was to make the big ships the core of a substantial post-war navy with 20,000 regular personnel. In 1944-45 the RCN took over two 10,000-ton British 6-inch cruisers, re-commissioned as HMC Ships Uganda and Ontario, provided crews (but not air groups) for two British escort carriers in the Atlantic, while beginning to organize an RCN air arm. Uganda joined the new British Pacific Fleet off Okinawa in April 1945, and its main role in operations until it departed for Esquimalt in July 1945 was to provide anti-aircraft fire to screen the British 
aircraft carriers against intense Japanese suicide bombing attacks. The dropping of atomic bombs on Hiroshima and Nagasaki in August 1945 brought the war to an end while HMCS Ontario was on passage to the Far East.

\section{Retrenchment and North American Defence, 1945-50}

The post-war objectives of the navy were soon cut to something less than half as the government undertook accelerated demobilization of the wartime forces, and imposed an 'interim' ceiling of 10,000 regular personnel for the RCN. The priority was economic 'reconstruction' and increased social welfare programs to avoid a return to the conditions of the Great Depression, universally feared in the country. The navy, while disposing of the vast anti-submarine fleet, retained the two cruisers and modern fleet destroyers, and was able to accept on loan the British light fleet carrier Warrior in 1946. The latter was replaced in 1948 by the larger Magnificent (15,700 tons) which, unlike Warrior, had been fitted for cold-climate operations. So strongly had wartime experience demonstrated the necessity of naval air power for independent national operations and to exercise command in alliance operations, that the navy devoted as much as a third of its strained resources to development of the new air arm. The central shore establishment was the former RCAF Station Dartmouth, on the east side of Halifax harbour, which was transferred to the navy in 1948 and renamed HMCS Shearwater. ${ }^{16}$

The emerging Cold War with the Soviet Union, and the continued acceleration of changes in weapons technology raised other challenges. The capabilities of strategic bombers and long-range submarines, both of which the Soviets were aggressively developing, posed a direct threat to North America, and made the Arctic the potential central front in a conflict between East and West. In 1946 the Canadian and American forces initiated planning under the Permanent Joint Board on Defence to meet the Soviet threat, and soon thereafter the RCN began to standardize on US Navy communications and operational methods. Arctic operations were a priority, not least because the US Navy, which began large annual northern exercises in 1946, did not recognize Canadian sovereignty in the waters within the Arctic Archipelago. The navy arranged to send participants on US warships, and made its own small forays, which required elaborate logistical arrangements and had to be carefully planned for the summer months when ice conditions were most favourable, to avoid damage to the navy's vessels. The naval staff was keenly aware of the importance of the Arctic, but did not have the ice-capable ships or other resources needed to develop a more substantial presence. ${ }^{17}$

16 J.D.F. Kealy and E.C. Russell, A History of Canadian Naval Aviation, 1918-1962 (Ottawa: Naval Historical Section, Canadian Forces Headquarters, 1965), the official history. For recent research see Michael Whitby, "Fouled Deck: The Pursuit of an Augmented Aircraft Carrier Capability for the Royal Canadian Navy, 1945-1964," 2 parts, The Canadian Air Force Journal 3:3 (Summer 2010), 2-13 and ibid., 3:4 (Fall 2010), 7-20.

17 Elizabeth B. Elliot-Meisel, "Arctic Focus: The Royal Canadian Navy in Arctic Waters, 19461949," The Northern Mariner/Le marin du nord IX:2 (April 1999), 23-39; Peter Kikkert and P. Whitney Lackenbauer, "Setting an Arctic Course: Task Force 80 and Canadian Control in the Arctic, 1948," ibid., XXI:4 (October 2011), 327-58. 
As it was, the service had to re-orient development of the fleet. Paradoxically, the cruisers that had so long been the aspiration for Canadian naval expansion had only a limited role in view of the Soviet focus on submarines. They served as training vessels, showing the flag on international cruises. The fleet destroyers, procured because of their surface gunnery and torpedo power, underwent reconstruction beginning in 1947-48 to replace these weapons with high-angle anti-aircraft guns and Squid anti-submarine mortars, the most advanced systems developed during the war. Work began in 1948 for a uniquely Canadian design, shaped by anti-submarine operations in the supremely demanding North Atlantic theatre during the war, for an ocean-going anti-submarine, anti-aircraft destroyer-escort. In 1950 the navy purchased 75 US Grumman Avenger aircraft, a wartime light bomber that had proven itself in carrier anti-submarine operations, as the primary attack type for Magnificent's air groups.

Western assessments that the Soviet Union, because of the grievous losses and devastation during the war, could not undertake early offensive operations were smashed by the sudden Soviet blockade of West Berlin in 1948. Canada, while cautiously refusing any part in the allied airlift over the winter of 1948-9 that sustained Berlin, took a leading role in the creation of a new western alliance, the North Atlantic Treaty Organization, concluded in Washington in April 1949.

\section{Hot War, Cold War, and Expansion, 1950-63}

A renewed challenge to the West came on 24 June 1950 when the forces of North Korea, in what had recently been the Soviet post-war zone of occupation, invaded the Republic of Korea in the south. A Soviet boycott of the United Nations enabled that organization to approve military operations against aggression, under the leadership of the United States. Canada fully supported the resolution, and the navy, despite continuing upheavals of the post-1945 demobilization and reorganization of the regular force under tight budget constraints, was able to provide a rapid response. On 5 July 1950 three destroyers, HMC Ships Athabaskan, Cayuga, and Sioux, sailed from Esquimalt with full war stores, and arrived on 30 July at the US base at Sasebo, Japan, which was to support the Canadian force. The Canadian ships mostly operated independently of each other under Allied command in a variety of tasks: screening US and British aircraft carriers; identifying and boarding suspicious coastal craft to search for enemy supplies and personnel; gunfire support for United Nations ground troops; and interdiction of enemy supplies by 'trainbusting' destruction by gunfire of trains that ran along the enemy coast. Canada maintained a force of three destroyers until late in 1954, more than a year following the uneasy armistice reached in July 1953, with a single destroyer remaining on station until September 1955. A total of eight destroyers, four from each coast, kept up this commitment in year-long deployments; the east coast ships circumnavigated the globe on each mission. ${ }^{18}$

One of the important results of the Korean War was the build-up of standing

18 Thor Thorgrimsson and E.C. Russell, Canadian Naval Operations in Korean Waters, 19501955 (Ottawa: Naval Historical Section, Canadian Forces Headquarters, 1965). 
forces in NATO. Western nations were convinced that the Soviets had sponsored the North Korean offensive to distract the West from Europe, and Canada, as a committed member of the alliance, fully participated in this large-scale rearmament. This was a first in Canadian history: the creation of substantial, professional armed forces in peacetime, ready for immediate action under alliance command in the event of a crisis. The defence budget tripled from $\$ 607$ million in 1950 to $\$ 1.9$ billion in 1952 and remained at $\$ 1.7$ to $\$ 1.8$ billion until the late-1950s, about 25 percent of all federal government spending. The regular forces grew to over 100,000 personnel, peaking at 120,000 in 1963, of which 20,000 were navy.

For the western navies the organization and tasks established under the Supreme Allied Commander Atlantic - a hat worn by the commander-in-chief US Atlantic Fleet at Norfolk, Virginia - in 1951-52 virtually recreated the command structure and tasks that had existed in the latter part of the Second World War. The main mission was to support the new Supreme Allied Commander Europe, including the safe and timely arrival of convoys carrying reinforcements and supplies from North America in the face of interdiction by the expanding Soviet submarine fleet. The RCN's Flag Officer Atlantic Coast (FOAC) commanded the Canadian sub-area, which expanded the Canadian Northwest Atlantic theatre of 1943-45 out to the southern tip of Greenland. The US commander-in-chief Atlantic Fleet was triple-hatted, also as commander in the western Atlantic for the protection of North America, in addition to his role as SACLANT. The Canadian FOAC was responsible to the American admiral for Canadian-American continental defence arrangements. ${ }^{19}$

The RCN initially met its commitment with the single carrier, 12 fleet destroyers procured during or after the war, and by repurchasing and modernizing 18 of the frigates that had originally been completed in 1943-44. New ships joined the fleet just as technological revolutions were transforming naval warfare. The first batch of seven St. Laurent-class anti-submarine destroyers, whose design had begun in 1948, commissioned in 1955-57, after delays and cost over-runs inevitable for the first major warship to be designed in the country. ${ }^{20}$ Their main weapons system, hull-mounted sonar and Limbo anti-submarine mortars, had an effective range of a few thousand yards, which was very good against snorkel-equipped conventional submarines. Exercises by the lead ship St. Laurent with the US nuclear submarine Nautilus, however, immediately demonstrated that the new destroyers lacked the speed and weapons-range to counter the nuclear submarines the Soviets were known to be developing. One response was to accelerate trials for the operation of heavy anti-submarine helicopters from destroyer-sized vessels, in which Canada led the world by developing the Beartrap haul down system. This equipment received a cable dropped from the hovering aircraft, then pulled the machine to the deck and locked it securely so that it would not be pitched over by the movement

19 Sean M. Maloney, Securing Command of the Sea: NATO Naval Planning, 1948-1954 (Annapolis, MD: Naval Institute Press, 1995), 150-52.

20 Michael A. Hennessy, "The State as Innovator: Controlling the command technology for warship construction in Canada, 1949-1965," in Peter A. Baskerville (ed.), Canadian Papers in Business History (Victoria, BC, 1993), 147-77. 
of the ship's hull in the Atlantic swell. Of the 20 destroyers commissioned by 1964, all developed from the original St. Laurent design, 7 were converted to helicopter carriers, 2 were built to that design, and 4 were converted to operate the long-range ASROC system of rocket-thrown torpedoes. ${ }^{21}$ The ships were also fitted with another Canadian innovation, variable-depth sonar, in which the transceiving equipment was mounted in a housing that was lowered by cable from the stern to reach temperature layers in the ocean that best carried sound, and thus increasing detection ranges.

In 1957 the light fleet carrier HMCS Bonaventure joined the fleet, replacing Magnificent. In 1946 the British had suspended construction of a light fleet carrier, and in 1952 had resumed work on behalf of Canada, upgrading the ship with an angled flight deck, to allow the simultaneous launch and recovery of aircraft, and a steam catapult for operation of heavy and jet aircraft. Bonaventure's strike aircraft were American twinengine propeller-driven Grumman CS2F Tracker anti-submarine bombers, a capable machine that would remain in service until the 1990s. The air defence squadron comprised McDonnell Douglas Banshee sub-sonic jet fighters.

Developing submarine technology also brought a new emphasis on forward offensive operations. Until the late-1950s, the main threat was from snorkel-equipped conventional submarines, which, aside from threatening allied convoys on transatlantic passage, would pose the same threat to Western Europe and North America as had the German campaigns in the Western Atlantic in 1944-45: the ability to lurk close off ports where sonar conditions are difficult, and possibly enter harbour approaches for attacks with torpedoes and mines. Thus, under Canada-US agreements, the RCN had developed a seaward defence organization that featured a new class of small wooden-hulled minesweepers with the ability to sweep sophisticated influence mines, together with traditional harbour defence equipment such as anti-submarine nets, and radar-controlled rapid-fire army coastal artillery that could dispatch a snorkel boat that had been forced to the surface.

From 1957, with indications the Soviets were developing submarines that could fire missiles against land targets from 500 miles (a range estimate later increased to 1500 miles), the emphasis shifted to distant offensive operations to catch submarines before they reached firing positions. Anti-submarine destroyers were also assigned to the west coast, to counter the Soviets' growing capabilities in the Pacific, the beginning of the balancing of the fleet between the west and east coasts that continues to the present day. The build-up of the RCAF's Maritime Air Group, with the new Canadian-built Canadair Argus long-range patrol bomber, and the American Lockheed Neptune was crucial to the new concept of operations. Arguses were also assigned to SACLANT, together with the carrier and main body of destroyers, for forward operations to catch submarines as they came through the Greenland-Iceland-United Kingdom gaps. The intention was that American and British ocean bed sonar arrays (SOSUS) together with the air patrols would refine contacts to areas that could be thoroughly searched by the surface groups. ${ }^{22}$

21 Shawn Cafferky, Uncharted Waters: A History of the Canadian Helicopter-Carrying Destroyer, $2^{\text {nd }}$ ed. (Halifax: Centre for Foreign Policy Studies, 2012).

22 Maloney, "Parry and Thrust: Canadian Maritime Forces and the Defence of North America, 
The need for warships on these missions to keep station hundreds of miles from the coast raised the lesson learned in mid-ocean convoy support operations during the Second World War: the necessity for at-sea refuelling and replenishment. The RCN's first operational support ship, the Canadian-designed and built HMCS Provider, commissioned in September 1963.

A new requirement, joint operations with the army, had suddenly appeared with the Israeli offensive against Egypt across the Suez Canal in 1956. Canada played a leading role in defusing the crisis by proposing the creation of a United National peacekeeping force to separate the combatants, and maintain a presence on the border between Egypt and Israel. In December 1956, HMCS Magnificent, in one of her last missions while in Canadian service, took on board a large part of the Canadian army force assigned to the mission - 406 personnel, 233 vehicles and their stores - and transported them to Suez.

The east coast navy and the Maritime Air Group of the RCAF demonstrated their growing capabilities for offensive anti-submarine warfare, and the nearly seamless cooperation that had developed between Canadian and US forces, in the Cuban Missile Crisis of October 1962. When President Kennedy imposed a naval blockade on Cuba, requiring the concentration of US Atlantic Fleet forces in the Caribbean area, RearAdmiral K.L. Dyer, Flag Officer Atlantic Coast, deployed the Canadian fleet and RCAF Maritime Air Group to cover waters from Newfoundland south to New England. Estimates, admittedly uncertain without access to Soviet records, are that the Canadians located and tracked two incoming Soviet submarines. ${ }^{23}$

The deployment was and remains controversial because Admiral Dyer ordered his forces to sea before the Canadian government approved. Conservative Prime Minister John Diefenbaker had reservations about Kennedy's precipitate action, and his failure to give early warning to, let alone consult, its partner in continental defence. Debate continues whether Dyer had the power to act, without the government's approval, under Canada-US continental defence agreements. ${ }^{24}$

\section{Armed Forces Unification and Retrenchment, 1963-89}

Defence became an issue in the election of April 1963 that brought Lester Pearson's Liberals into office with a minority government. The new minister, Paul Hellyer, sought to resolve two principal challenges. Firstly, alliance commitments had subsumed a distinct Canadian defence policy, as had been highlighted in the Cuban Missile Crisis. Each of the three services were slotted into particular and disparate roles that grew out of alliance rather than Canadian needs. Moreover, the general war for

1954-1962," the Northern Mariner/Le marin du nord XVIII:1 (January 2008), 39-54.

23 Peter T. Haydon, The 1962 Cuban Missile Crisis: Canadian Involvement Reconsidered (Toronto: Canadian Institute of Canadian Studies, 1993), and "Canadian Involvement in the Cuban Missile Crisis Reconsidered," The Northern Mariner/Le marin du nord, XVII:2 (April 2007), 39-65.

24 Brad Gladman and Peter M. Archambault, "Advice and Indecision: Canada and the Cuban Missile Crisis," Canadian Military History 23:1 (Winter 2014), 9-32. 
which the alliance was preparing now looked like it would be an exchange of nucleartipped missiles that would destroy civilization. In this new form of conflict, which seemed suicidal even to contemplate, the role of Canada and the other members of the alliance was little more than to protect the US nuclear arsenal, in missions that required increasingly specialized and expensive weapons systems. The second large issue was a shortage of funds, with the gradual decline of the defence budget since 1957-58 - even as the costs of new equipment of all types were soaring. Personnel costs were already draining capital funds while the services faced rust-out, especially the navy whose fleet included many Second World War hulls.

Hellyer's answer, in the 1964 defence white paper, was to integrate the three service headquarters in Ottawa in a 'Canadian Forces Headquarters' under a single chief of defence staff. Where previously the minister and the government had had to sort through often competing advice from all three services, each of whose programs were heavily invested in alliance roles, the intention was that proposals would now be coordinated from the very beginning by integrated staffs, under the single chief through whom the government could exercise more effective control. Headquarters integration was the first step in the full unification in 1968 of the three services into a single 'Canadian Armed Forces' merged with the department and to be managed from a 'National Defence Headquarters'.

Policy was spelled out in the 1964 white paper. Alliance commitments would be fulfilled as far as possible with existing equipment, but would be phased out as that equipment became obsolete. The focus of the new organization would be to build forces for Canadian priorities. The main element was 'Forces Mobile Command', which was to raise light air and sea transportable land brigade groups, with integral air support, for United Nations missions, or to fight 'brushfire wars' that threatened otherwise to escalate into major conflicts. Hellyer's ideas were heavily influenced by the Kennedy administration's new policy of 'flexible response' to aggression by the Eastern bloc and its proxies.

Economies resulting from unification of the triplicated army, navy, and air force support services were expected to pay for the equipment required for the Forces Mobile Command and its supporting elements. It was not to be. The government's top priority was increased social welfare programs, so the defence budget remained fixed as inflation eroded purchasing power, and long overdue improvements in pay increased personnel costs despite the fact the size of the forces began to shrink.

The navy's development was dictated by the budget available. One of Hellyer's first acts on entering office had been to cancel a new class of eight 'general purpose frigates', despite the fact the ships were designed for joint operations that would be the focus of Forces Mobile Command. In the end the navy got four Canadian-designed and built destroyers, the Iroquois class, that commissioned in 1972-73. These at 5300 tons displacement featured capabilities sought in the cancelled General Purpose Frigates: air defences (the Sparrow missile system), a 5-inch gun for naval gunfire support in joint operations, and accommodation for command staffs. Most important, each ship was able to operate two large helicopters. The fleet's capabilities were also enhanced by two 
additional operational support ships, built and designed in Canada, HMC Ships Preserver and Protecteur.

Financial constraints more profoundly shaped other major procurements. It had become clear by the mid-1950s that submarines were indispensable for anti-submarine warfare. Requirements for as many as eight submarines - and Hellyer himself suggested the need for nuclear boats to operate under the Arctic ice packs - ultimately became three British diesel-electric submarines of the Oberon class, selected because they were cheaper than the American Barbel class alternatives.

Yet, even with the disposal of all 30 Second World War-era destroyers and frigates, there were too few personnel to crew the new ships. In a heart-wrenching decision, in 1970 the navy paid off the carrier Bonaventure. In sum, during the latter half of the 1960s the RCN's fleet was cut nearly in half, from some 50 combatants to the 20 St. Laurent-type destroyer escorts, the 4 Iroquois-class destroyers, and 3 submarines, with helicopters now the only seaborne aviation. These decisions represented the cumulative judgements of senior staff since erosion of the defence budget had begun in the mid1950 s, that the only way in which the navy could achieve its ambitions of 'balance' in surface, sub-surface and aviation capabilities was by focusing on destroyer-sized combatants.

The navy's budget-driven decisions were in line with the dramatic changes imposed on the land and air services by Pierre Trudeau, who succeeded Pearson as prime minister in 1968. One of the difficulties for Hellyer's ambitious program was the refusal of Pearson to contemplate reductions in the country's alliance commitments. Pearson was an internationalist, and, profoundly unsettled as he was by the nuclear stand-off between East and West, he had devoted his career to increasing Canada's influence abroad, especially in Washington and London. Trudeau, a law professor from Quebec who had been educated at the Sorbonne in Paris as well as at Harvard in the United States, had a view of international relations that was not far removed from that of William Lyon Mackenzie King: the country should attend to its own concerns and not meddle in the affairs of the great powers. Only opposition from the defence department and the Department of External Affairs persuaded Trudeau not entirely to remove the 10,000 Canadian ground troops and air personnel stationed in Europe under NATO command; in 1969 Canada withdrew half of these forces. A new defence white paper in 1972 made defence of Canadian sovereignty the top priority. Yet Trudeau received an education about the profound importance of security to European nations with whom his administration made determined efforts to increase trade, but also the United States. By the inescapable facts of geography and history, Canada, to use Trudeau's words, was like a mouse in bed with an elephant.

Maritime Command, as the navy and the air force maritime patrol squadrons had been known since 1964, continued exercises in anti-submarine warfare with US and NATO forces, but at the same time increased effort in 'sovereignty' patrols. These included missions to support other departments in such things as the regulation of foreign fishing vessels, and Arctic operations, particularly by the maritime patrol aircraft, and also warship deployments to the limits possible with thin-hulled vessels. All the while, 
the navy regenerated itself within the unified services, building a shadow naval staff in the maritime directorates of National Defence Headquarters that worked closely with the operational Maritime Command headquarters at Halifax. Faced with the multiple challenges of unification, sharply-constrained budgets, and a government that questioned the most basic premises of Canada's role within the western alliance, the navy had - once more - to rethink from first principles what was truly essential. A fundamental point the staffs were able to demonstrate was that warships of 4000-5000 tons displacement were the smallest vessel that could dependably keep the seas in the challenging conditions on the country's ocean frontiers, and also carry out the whole range of national needs from constabulary missions to combat.

Even as Canada greatly trimmed its naval forces in the late-1960s to 1970s, the Soviets markedly expanded their international maritime capabilities and activities in all areas, from submarine and surface warships to fishing fleets and merchant shipping. Soviet fishing vessels were regularly present off Canada's coasts, often accompanied by oceanographic research and electronic intelligence gathering vessels; submarines frequently made submerged transits through Canadian operational zones. The prime minister came to see that maintaining anti-submarine capabilities was not to join in a destabilizing technological race between the Cold War blocs, but rather an element in control of ocean frontiers that was as important to sovereignty as to alliance relations.

In December 1977 the Cabinet agreed to the construction of 6 general purpose frigates of 4000 tons displacement to replace the oldest of the St. Laurent type. Cabinet also confirmed that surface fleet strength should continue at the existing level, that is 24 destroyers and frigates; the 6 new frigates were to be the first phase in replacing all 20 of the St. Laurents. The prominent American naval commentator Norman Friedman expressed doubts that 'one for one' replacement would be achieved, referring to the alliance-wide difficulties because of the high costs of new technology, and the budgetary constraints of western governments. He also, again referring to lengthening lead times in all western nations because of design challenges, predicted the new frigates would be a long time in coming. ${ }^{25} \mathrm{He}$ was right on both scores. The new Conservative government of Brian Mulroney increased the order to 12 frigates soon after the first keel was laid in 1986. The Conservative platform had included revitalization of the armed forces so that the country could play a fuller part in the intensifying Cold War of the 1980s, and its most dramatic proposal was to procure 10 to 12 nuclear submarines, in part to assert Canadian sovereignty in Arctic waters. This ambitious plan was overtaken by the end of the Cold War starting with the fall of the Berlin Wall in 1989. The Canadian government, in fiscal crisis, was quick to declare a 'peace dividend' and cut back the defence budget, the largest spending program fully under the federal government's control, that is not involving disbursements to other levels of government.

\section{Fleet Renewal and Crises in the Post-Cold War World, 1989-2001}

Fleet renewal continued, on a more modest basis. The 12 'Canadian Patrol

25 Norman Friedman, “The Canadian Patrol Frigate, International Defence Review 6/1984. 
Frigates', named the Halifax class for the lead ship in the program, commissioned in 1991-96. At the same time, the 4 Iroquois-class destroyers were refurbished and modernized; vertically-launched Standard missiles giving them an area air defence capability that complemented the self-defence weapons in the frigates. In 1997-99, twelve 925-tonne 'Maritime Coastal Defence Vessels', the Kingston class, commissioned. These had minesweeping capabilities, and also the sea-keeping qualities and endurance for sovereignty patrols, including surveillance of the fisheries. Their crews were envisioned to be all reservists on call out, an effort to address perennial personnel shortages. The three Oberon-class submarines were replaced by purchasing 4 British Upholder-class diesel-electric submarines originally completed in 1990-93, and then laid up in reserve after brief service. They commissioned in the Canadian navy as the Victoria class in 2000-04. ${ }^{26}$

Paradoxically, during the 1990s, even as the government imposed deep defence spending cuts, the armed forces were intensely engaged in a succession of international deployments to war zones. Far from ushering in a new age of peace, the end of the Cold War saw simmering regional tensions and stresses within failing or failed states flare into violence. When in 1990 Iraq invaded Kuwait, and the United Nations approved armed sanctions, the navy once more enabled the Canadian government to respond quickly. The main Canadian contribution was a task group comprising the Iroquois-class destroyer Athabaskan, the St. Laurent-variant Terra Nova, and the replenishment ship Protecteur. These ships were all well past mid-life, having been commissioned respectively in 1972, 1959, and 1969, but the Halifax dockyard was able quickly to fit them with equipment in stock for the new Canadian Patrol Frigates and modernization of the Iroquois class, including the Phalanx close-in defence system on all three ships, and Harpoon anti-ship missiles in Terra Nova. Still the ships lacked modern air defences, so the air force dispatched an enlarged squadron of CF-18 fighters to Qatar to fly cover for the group. A naval officer, Commodore Kenneth Summers, commanded this first Canadian joint force to be deployed overseas. Because of the priority the navy had always given to maintaining communications and data transmission systems that were compatible with American systems, and had such extensive experience in operations with the Americans and other NATO navies, the Canadian ships took a prominent part in the coalition from the beginning. During the build-up of forces, the Canadian ships were extremely active in the blockade of Kuwait and Iraq, carrying out hundreds of interceptions of suspicious vessels. With the beginning of the coalition assault in January 1991, the senior Canadian naval officer afloat, Captain D.E. Miller in Athabaskan, assumed command of the coalition logistics force, some twenty replenishment ships (including Protecteur) and ten escorts. ${ }^{27}$ This was precisely the kind of prominent command role Canada seeks for its international contingents.

From 1992 to 1995 Canadian warships and maritime patrol aircraft, operating as

26 The submarines were 'named' in the UK, to be commissioned after arrival in Canada. The fourth submarine to be accepted - Chicoutimi - has yet to be commissioned, as it suffered a tragic fire en route to Canada, requiring extensive repairs, and is only planned to return to service as this journal goes to print in autumn 2014.

27 Jean H. Morin and Richard H. Gimblett, Operation Friction: The Canadian Forces in the Persian Gulf, 1990-1991 (Toronto: Dundurn, 1991) 
part of NATO forces, undertook several missions in the Adriatic to blockade the war-torn former Yugoslavia against arms shipments. In Somalia, 1992-93, the replenishment ship Preserver functioned as a floating headquarters for land forces endeavouring to restore order and deliver humanitarian supplies in violent and chaotic conditions ashore; this was an important precedent for 'joint' operations. Starting in 1997, the new Canadian Patrol Frigates, having proved themselves fully interoperable within US formations, began to join American carrier groups for the blockade of Iraq in response to Saddam Hussein's refusal to comply with United Nations arms inspections.

\section{War on Terror, 2001-14}

International efforts to address regional tensions did nothing to prevent the attacks on New York's World Trade Centre and the Pentagon in Washington on 11 September 2001. Those disasters instantly demonstrated the linkage between instability in distant failed and failing states and Canadian security. ${ }^{28}$ 'Ground zero' was less than 400 miles from southern Ontario and Quebec, and claimed the lives of some 26 Canadians who were in the World Trade Centre that day. Canadian military personnel in the North American Aerospace Command took a prominent part in the immediate response to the disasters, which included the shut-down of American air space; Canada opened its airports to some hundreds of flights diverted from US destinations, and Canadian communities provided accommodation for the tens of thousands of passengers who were delayed for the better part of a week or longer.

As so often before, the navy was Canada's first contribution to alliance appeals for military action. In October to December 2001, six Canadian warships took up station in the Arabian Sea as part of the US Navy task force that mounted operations in Afghanistan against the pro-terrorism Taliban regime. In contrast to the 1990-91 deployment to the Persian Gulf, there was no need for improvisation or compromise for operations in littoral waters. The warships, which included the modernized destroyer HMCS Iroquois and four of the new general purpose frigates, had full suites of air defence and close-in weapons. The Canadian group, in its escort missions, exercised tactical control over major US warships, evidence of the capabilities of the renewed Canadian fleet and the long experience of their crews in multi-national operations. In the spring and summer of 2002, the Canadian group took a leadership role in coalition naval forces that patrolled the Gulf of Oman against movements of terrorist personnel, equipment, and supplies. From the fall of 2002 to the summer of 2003, the Canadians protected the heavy shipping traffic in the Strait of Hormuz that is one of the arteries of the international economy. Canadian Commodore Roger Girouard assumed command of the coalition escort force to establish its independence from the US invasion of Iraq in

28 The author was attending an international meeting of historians at the US Naval Historical Center, in the Washington Navy Yard, only about five kilometres across the Potomac River from the Pentagon, at the moment of the attack. Notable were the stoic calm of our hosts, their kindness and efficiency in assuring the group of our security, and the spontaneous outrage and sense of solidarity with our American friends among the scholars from other countries. 
March 2003, in which Canada and some other western alliance members decided not to participate because of the lack of United Nations endorsement. ${ }^{29}$

Since the intense effort of 2001-03, the navy has maintained at least one frigate or destroyer regularly on station with coalition forces in the Persian Gulf area, and in recent years these ships have taken a prominent part in anti-piracy patrols off the horn of Africa. This commitment is a substantial one for a surface fleet of only fifteen oceangoing combatants. It has had to be met, together with alliance exercises and sovereignty patrols (in which the Pacific and Arctic have assumed greatly increased importance), and emergencies such as the Haitian earthquake in 2008 that brought the immediate dispatch of a Canadian task group for humanitarian relief, in the face of renewed austerity. The large Canadian land force, tactical air, and air-lift commitment to Afghanistan in 2002-11 has had first draw on budgets and people, including naval personnel in 'purple' (unified) support positions and such urgently needed specialties as explosives clearance to counter the improvised explosive devices that inflicted heavy casualties on alliance forces.

Although the government announced a $\$ 36.8$ billion 'national shipbuilding procurement strategy' in 2010 for ship replacement, the first hulls will not be launched until late in the present decade. Already in 2000 the navy had to pay off one of the four destroyers, Huron, for lack of personnel, and the hull, stripped of equipment to sustain the remaining three destroyers, was then disposed of in a firing exercise in 2007. In 2014, a second destroyer, HMCS Iroquois had to be laid up because of evidence that her 42-year-old hull is rusting out, and HMCS Protecteur, one of the three still older replenishment ships, suffered a serious engine room fire that has removed her from service, while the frigates are now being cycled through extended mid-life refits and modernization.

Against these challenges the government's restoration in summer 2011 of the traditional names of the three environmental components of the armed forces, including 'Royal Canadian Navy', was a small but welcome gesture. At the least it serves as a reminder that in its first incarnation, 1910 to 1968, the RCN endured greater challenges and still was ready at the time of need.

Over the course of the past century, the Royal Canadian Navy has proved indispensable in asserting sovereignty over the nation's vast ocean frontiers, and providing the nation with military forces ready to deploy in the event of major world crises. Over and again, Canadian governments across the political spectrum have seen the need for, and committed to fund, the renewal of the fleet at critical junctures, not always as promptly or as fully as called for by naval planners, but consistently enough to establish that the RCN indeed is a navy of necessity.

29 Richard Gimblett, Operation Apollo: The Golden Age of the Canadian Navy in the War against Terrorism (Ottawa: Magic Light Publishing, 2004). 